\title{
Study of foundations in Ukraine from the eleventh to eighteenth centuries and their preservation and conservation methods: Experiences
}

\author{
Mykola Orlenko - Yulia Ivashko - Justyna Kobylarczyk \\ - Dominika Kuśnierz-Krupa
}

Doctor of Science, Professor Mykola Orlenko, Honorary President of the Ukrrestavratsiia Corporation

Kyiv National University of Construction and Architecture

Ukraine

e-mail: n_orlenko2012@ukr.net

ORCID:0000-0002-4154-2856

Doctor of Science, Professor Yulia Ivashko

Kyiv National University of Construction and Architecture

Ukraine

e-mail: yulia-ivashko@ukr.net

ORCID: 0000-0003-4525-9182

Professor Justyna Kobylarczyk

Cracow University of Technology, Faculty of Architecture

Poland

e-mail: justyna.kobylarczyk@pk.edu.pl

ORCID: 0000-0002-3358-3762

Professor Dominika Kuśnierz-Krupa

Cracow University of Technology, Faculty of Architecture

Poland

e-mail: dkusnierz-krupa@pk.edu.pl

ORCID: 0000-0003-1678-4746

Muzeológia a kultúrne dedičstvo, 2022, 10:1:33-51

DOI: $10.46284 / \mathrm{mkd} .2022 .10 .1 .3$

Study of foundations in Ukraine from the eleventh to eighteenth centuries and theirpreservation and conservation methods: Experiences

This paper is a report on experience collected during archaeological studies of structures in the territory of Ukraine. It discusses the archaeological study of architectural monuments over the period of the operation of the Ukrrestavratsiia Corporation and presents the observation that most known varieties of masonry systems, featuring different combinations of materials and mortars, were observed in findings dated to the period of the Kyivan Rus, and that the list of foundation schemes present was limited to a few types. It was also found that of the schemes observed, the Old Russian scheme displayed an evolution. The study also highlights the significance of the role of foundation musealisation in the restoration and reconstruction of damaged architectural monuments.

Keywords: archaeological research, architectural monuments, foundations, structural schemes, Kyivan Rus.

\section{Introduction}

Archaeological research is an essential part of restoration work. In Ukraine, many architectural monuments from different periods have survived but not all are in the same condition: some are preserved only fragmentarily, while the only elements of others that still exist are their 
M. Orlenko et al.: Study of foundations in Ukraine from the eleventh to eighteenth centuries...

foundations. This is especially true of structures from the Old Russian (the so-called RussianByzantine) period. Most of them were destroyed during the princely internecine wars and the Tatar-Mongol invasion. These military activities also adversely impacted the structures from the Middle Ages.

In general, among the original materials used to construct the supporting structures dated to between the eleventh and nineteenth centuries and located in Ukraine, we can see different types of timber, varieties of natural stone, brick and metal, with each having distinct advantages and disadvantages. Archaeological research has provided substantiated information about how various historical periods affected the change in the building materials used, so it can form a basis for comprehensive restoration. In this case, the study of materials and the state of existing authentic foundations is the most significant, as the statics of a monument's footing structure play a crucial role in its functioning. In addition, as a rule, whenever a structure is in an alarming condition, its restoration begins with the reinforcing of its foundations.

The literature and other academic sources analysed were grouped by topic, as follows:

1) general problems associated with the degradation of historical and cultural heritage, artifact musealisation, problems of cultural heritage, ${ }^{1}$

2) technologies for the testing and restoration of stone in architectural monuments; ${ }^{2}$

3) archaeological research of the foundations of architectural monuments; ${ }^{3}$

4) reproduction of destroyed monuments with the possibility of the museumification of authentic fragments; ${ }^{4}$

5) reconstruction of structures based on historical evidence. ${ }^{5}$

The study of base sources allowed us to prove the commonality of the problems of preserving historical artifacts and the problems of the cultural environment's degradation. The

\footnotetext{
${ }^{1}$ SPIRIDON, Petronel, and SANDU, Ion. Muselife of the life of public. In: International Journal of conservation science 7 (1), 2016, pp. 87-92; PUJIA, Laura. Cultural heritage and territory. Architectural tools for a sustainable conservation of cultural landscape. In: International Journal of Conservation Science 7 (S. Iss. 1), 2016, pp. 213-218; KUŚNIERZ-KRUPA, Dominika. Protection issues in selected European historic towns and their contemporary development. In: E3S Web of Conferences 45, 2018, pp. 1-8; ORLENKO, Mykola. The system approach as a means of restoration activity effectiveness, In: Wiadomości Konserwatorskie - Journal of Heritage Conservation, 57, 2019, pp. 96--105.

2 LUVIDI, Loredana, MECCHI, Anna Maria, FERRETTI, Marco, SIDOTI, Giancarlo. Treatments with self-cleaning products for the maintenance and conservation of stone surfaces. In: International Journal of Conservation Science 7 (S. Iss. 1), 2016, pp. 311-322; JASIEŃKO, Jerzy, BEDNARZ, Lukasz, MISZTAL, Witold, RASZCZUK, Krzysztof. Konserwacja konstrukcyjna i wzmacnianie murów historycznych. In: B. Szmygin (ed.), Trwała ruina II. Problemy utryymania i adaptacji. Ochrona, konserwacja i adaptacja zabytkowych murów. ICOMOS, 2010, pp. 57-68, KUŚNIERZ-KRUPA, Dominika. Historical Buildings and the Issue of their Accessibility for the Disabled. In: IOP Conference Series: Materials Science and Engineering, 603 (5), 2019, pp. 1-6.

${ }^{3}$ PETICHINSKIY, Volodymyr, GOVDENKO, Georgij, and GOVDENKO, Marionila. Report on the dismantling of the ruins of the Assumption Cathedral - an architectural monument of the XI-XVIII centuries in the Kyiv-Pecherkyi State Historical and Cultural Reserve in 1962-1963. Kiev, 1964, pp. 10-16; SITKARYOVA, Olga. Assumption Cathedral of the Kyiv-Pechersk Lavra. Kyiv, 2000.

${ }^{4}$ ORLENKO, Mykola. St. Michael's Golden-Domed Monastery: methodological principles and chronology of reproduction. Kyiv, 2002; ORLENKO, Mykola. St. Volodymyr's Cathedral in Chersonesos: methodological principles and chronology of reproduction. Kyiv, 2015.

${ }^{5}$ TREHUBOV, Kostiantyn, DMYTRENKO, Andrii, KUZMENKO, Tetiana, VILDMAN, Igor. Exploration and restoration of parts of Poltava's town fortifications during the Northern War and elements of field fortifications used in the Battle of Poltava in 1709. In: Wiadomości Konserwatorskie - Journal of Heritage Conservation 61, 2020, pp. 91-100; IVASHKO, Yulia, DMYTRENKO, Andrii, PAPRZYCA, Krystyna, KRUPA, Michał, KOZłOWSKI, Tomasz. Problems of historical cities heritage preservation: Chernihiv Art Nouveau buildings. In: International Journal of Conservation Science 11 (4), 2020, pp. 953-964.
} 
body of experience analysed indicated the possibility of the museumification of authentic foundations in the case where a destroyed or damaged structure is reproduced.

\section{Materials and methods}

As restoration should be seen as observing systemic integrality, the following academic methods were applied: historical analysis (to characterise archaeological remains from different historical periods); comparative analysis (to compare authentic remains of structures from different periods and formulate hypotheses concerning changes in the use of building materials and structures from period to period); the graphical-analytical method (for the graphical analysis of artefacts); and, principally, the method of system-structural analysis, according to which a building - an architectural object - is presented as a systemic integrality with a division into hierarchical levels. The study was based on the data collected during the restoration of Ukrainian monuments, carried out by specialists from the Ukrrestavratsiia Corporation, and on the findings of archaeological research performed on monuments in Poland.

\section{Results and discussion}

The archaeological study of monuments in the territory of Ukraine found that strip, isolated, slab and pile footings were used during different historical periods. The distribution of strip and isolated footings in all periods, except for the beginning of the twentieth century, was found. As special attention is paid to the monuments of the Byzantine period, the authentic materials and structures from the Kyivan Rus period in the churches of Kyiv, Chernihiv, Ovruch, and Galych were examined in detail, as was the distribution of: foundations of the opus mixtum type (mixed construction technique, masonry from dimension stone and plinthiform bricks on mortar); rubble stone foundations from uncut stone; cement-rubble foundations; foundations from plinthiform brick, limestone or sandstone; and, in wooden structures (these were the most numerous, but they did not survive), from oak logs.

The structures of buildings dated to ancient Russian times and those of the Middle Ages and the Renaissance (the fourteenth, fifteenth and sixteenth centuries) were compared and it was observed that foundations of the opus mixtum type disappeared after the Tatar-Mongol invasion and the decline of Kyivan Rus, and masonry foundation variation diminished significantly in comparison with in ancient Russian times. In particular, rubble stone foundations from boulders, limestone, sandstone and oak logs became common. However, the types of mortars became more diverse; especially in the sixteenth and seventeenth century, the laying of foundations made of limestone and flat limestone utilised clay mortar with powdered overburnt brick, and lime mortar with powdered overburnt brick (the surface structure). During the period of the predominance of the Baroque style in the seventeenth and eighteenth centuries the role of bricks became more significant, as did the use of stone in foundations; therefore, along with foundations from limestone, sandstone or oak logs, foundations with burnt bricks or rubble concrete (stone, brick) were laid.

The experience of colleagues from Poltava was explored, especially the case of the Assumption Cathedral on Ivanova Gora, which was destroyed in the 1930s. A. Dmytrenko reported that the authentic eighteenth-century foundations were made of local red bricks bound with lime mortar, and large granite blocks were laid in the corners of the masonry structure. 
Thus, archaeological investigation of foundations found that the most pronounced changes in foundation system development took place during the times of Kyivan Rus, while subsequent centuries saw little in the way of experimentation. The appearance of foundations from burnt bricks in the seventeenth century was a notable development. The variety of materials used and structures decreased, and the spread and improvement of the schemes of ancient Russian times (foundations from limestone and sandstone, rubble and cement, and oak logs) were recorded. It was established that oak log foundations were laid under both wooden and stone buildings.

Archaeological studies provided information about both masonry materials and binders and mortars used throughout the various historical periods and in specific masonry types:

1) rubble foundations from between the ninth and twelfth centuries - composed of sandstone, granite, quartzite, limestone bound with lime and lime with powdered overburnt brick mortars;

2) rubble foundations from between the ninth and twelfth centuries - with wooden sill plates on the ground, fastened with stakes or crutches - made of sandstone, granite, quartzite, limestone on clay mortar, lime with powdered brick mortar (for footing), lime and opus signinum (for stone) mortars;

3) rubble foundations from between the ninth and twelfth centuries of the opus mixtum type - from sandstone, granite, quartzite with courses of plinthiform bricks on the lime mortar with powdered overburnt brick;

4) rubble foundations from the twelfth century - broken plinthiform bricks and crushed stone bound with clay mortar (below grade) and lime mortar with powdered brick (for the surface structure or the entire building) solutions;

5) foundations from the twelfth century made of plinthiform bricks bound with lime and lime with powdered overburnt brick mortars.

As noted above, the main changes in foundations after the Mongolian time primarily concerned the improvement of already existing masonry schemes and changes in the types of mortars. In ancient Russian times, we found lime, lime with powdered brick or opus signinum mortars, but in the sixteenth and seventeenth centuries, clay (with powdered brick) and lime (with powdered brick) mortars were used. The surface structure was built with the use of lime mortar, while the underground structure employed clay mortar. Such changes in mortar composition were caused by a change in the masonry material in the foundations in comparison with ancient Russian times: whereas sandstone, granite, quartzite, limestone, plinth and plinth with irregular boulders were used for laying foundations during the times of Kyivan Rus, in the Middle Ages limestone, flat limestone and sandstone were used.

Based on an analysis of the structures of ancient Russian foundations, the following conclusions could be drawn about the construction of buildings of the Middle Ages and the early modern period:

1) foundations from the sixteenth and seventeenth centuries were built from limestone and flat limestone with the use of clay (with powdered brick) and lime (with powdered brick) mortars (for surface structures);

2) foundations from between the fourteenth and seventeenth centuries were made from sandstone bound with lime mortar; 
3) foundations dated to the fifteenth and sixteenth centuries (found in defensive structures in Podillia) were made of sandstone and clay mortar (below grade) and lime mortar (the surface structure).

Archaeological studies further testified to the change in the structures of the foundation masonry during the Baroque in the seventeenth and eighteenth centuries, when foundations were built using red overburnt brick and clay, lime and clay-lime mortar. Archaeological study of St Michael's Golden-Domed Cathedral

In the beginning of the reconstruction of St Michael's Golden-Domed Monastery in forms of the High Ukrainian Baroque, the following structures of St Michael's Golden-Domed Cathedral complex had survived: the remains of the foundations of St Michael's GoldenDomed Cathedral and its belltower, the Refectory Church, two buildings with monastic cells, a singing building, the foundations of one part and a fragment of the monastery fence, and cellars. ${ }^{6}$

The foundations of the Old Russian core of St Michael's Golden-Domed Cathedral were made of large rubble stone bound by opus signinum mortar. Upwards splayed foundation ditches were dug for these foundations, the bottom of which were reinforced with wooden sill

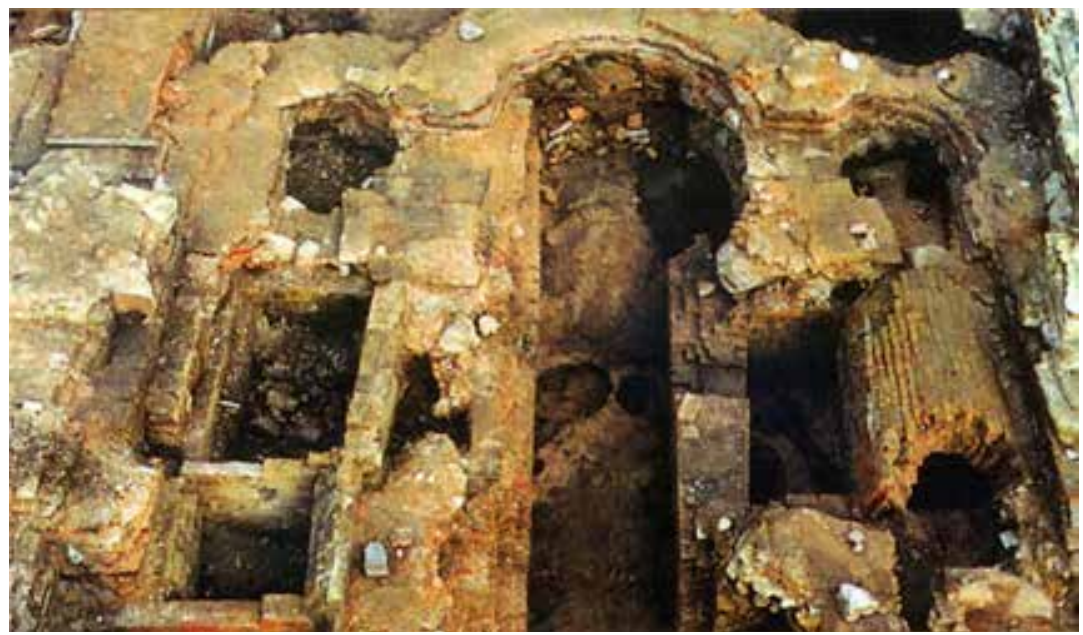

Fig. 1: Fragment of ancient foundations of St Michael's Golden-Domed Cathedral.

Photo: [in:] Collection of the Ukrrestavratsiia Corporation

plates fastened with iron pins and grouted with mortar with powdered overburnt brick. The foundation ditches were filled with rubble stone and grouted with the mortar with powdered overburnt brick, the colour of which was slightly lighter than the colour of the cathedral walls. As a result of archaeological research, it was established that the foundations of the cathedral featured a cross strip system of brick and rubble masonry, and at the intersection of the strips, there isolated column foundations were found (Fig. 1).

The Old Russian foundations from the twelfth century consisted of a layer-by-layer structure, where the lower layer $(1.2-1.5 \mathrm{~m})$ was composed of cyclopean masonry consisting of irregularly shaped stone blocks with sizes ranging between 20 and $70 \mathrm{~cm}$ without mortar (moreover, the cavities between the stones were filled with local soil); and the intermediate layer $(0-0.5 \mathrm{~m})$ consisted of rubble and cement masonry (from crushed plinthiform bricks and

${ }^{6}$ ORLENKO, St. Michael's Golden-Domed Monastery..., p. 160. 


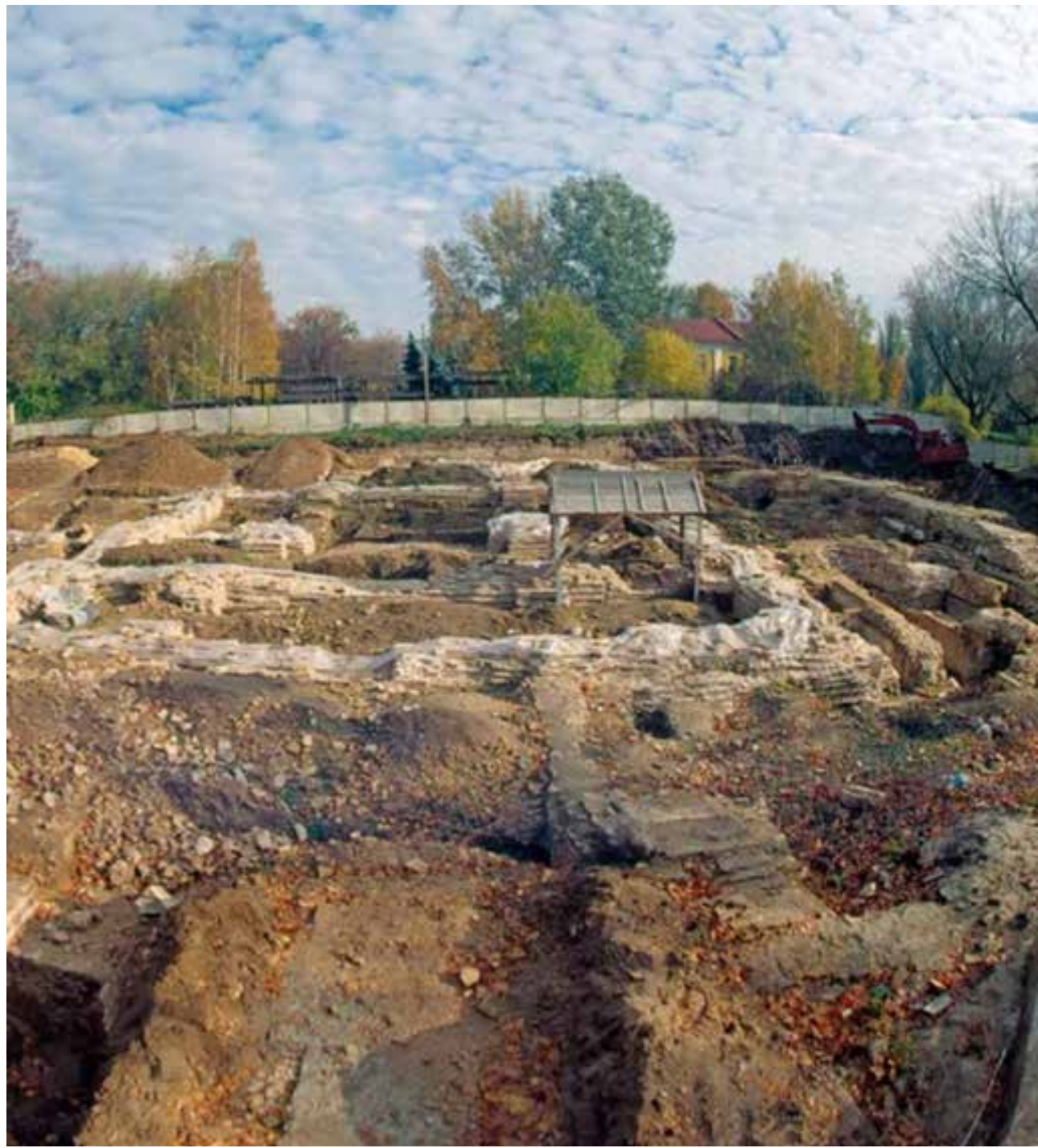

Fig. 2: Ancient foundations of St Michael's Golden-Domed Cathedral. Photo: [in:] Collection of the

Ukrrestavratsiia Corporation

5-20 $\mathrm{cm}$ boulders) with lime mortar; while the top layer $(0.4-0.8 \mathrm{~m})$ was made up of plinthiform bricks and lime mortar ${ }^{7}$ (Fig. 2).

Strip foundations from between the eleventh and the thirteenth centuries were made in the form of brick and lime and lime-clay mortar, with stones in column and strip foundations left unbound (Fig. 2).

The remains of the foundation masonry of the cathedral represent a cross-strip system, made of brick and rubble masonry (Fig. 3).

The crossing points of the strips form pillars - the foundations of the columns. The crosssection of the twelfth-century foundations formed a layer-by-layer structure: the upper layer, from 0.4 to $0.8 \mathrm{~m}$ thick, consisted of plinthiform brick with lime mortar; the middle layer - up to $0.5 \mathrm{~m}$ - was rubble cement masonry and lime mortar, while broken plinthiform bricks and

${ }^{7}$ Ibidem. 


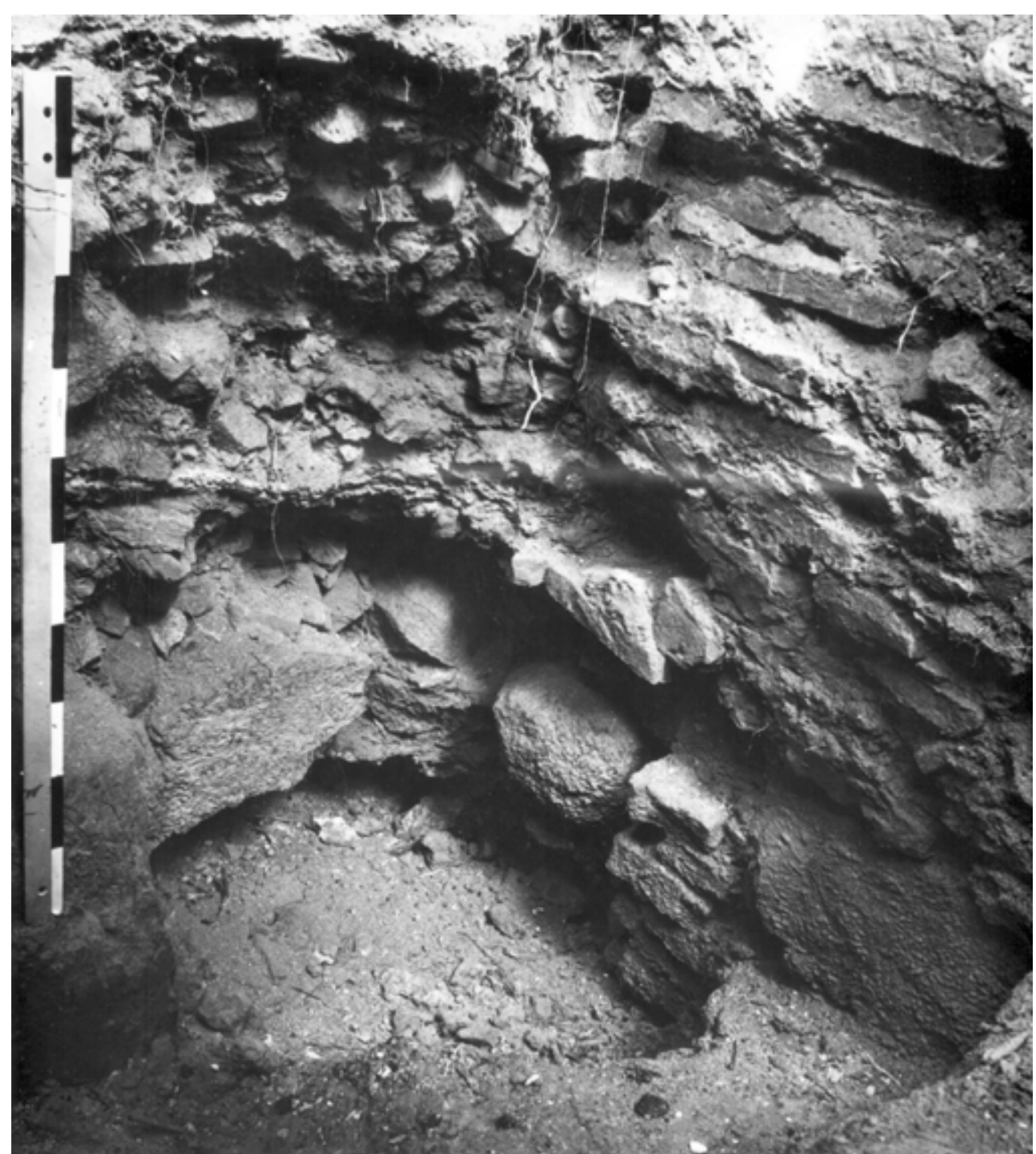

Fig. 3: Ruins of old masonry foundations of St Michael's Golden-Domed Cathedral. Photo: [in:] Collection of the Ukrrestavratsiia Corporation

irregularly shaped stone blocks ranging in size between 5 to $20 \mathrm{~cm}$ were used as infill. The bottom layer, from 1.2 to $1.5 \mathrm{~m}$, consisted of cyclopean masonry with 20 to $70 \mathrm{~cm}$ irregularly shaped stone blocks without mortar. As noted above, the gaps between the stones were filled with local soil.

During the observation of the technical condition of the preserved foundations, the strength of brickwork layers - the bricks (plinthiform bricks) and mortar - was determined.

The foundations of the western and northern walls of the western aisle, dated to the Baroque period and made of crushed bricks and stone rubble with powdered brick mortar, have been partially preserved. As a result of excavations in the north aisle, it was found that the foundations of the north wall of the aisle were made of stone rubble and crushed plinthiform bricks with powdered brick mortar. 
The archaeological investigation provided evidence on the techniques and materials used in building the foundations of the period of St Michael's Cathedral's extension in the late seventeenth and early eighteenth centuries, as well as on the chronology of these works. It was found that northern aisle was added first, followed by the southern aisle in 1709, while the western aisle was built later in the eighteenth century. The foundations of the north aisle were found to consist of a red brick outer layer and internal brickwork backfilling with rubble stone (from the partially disassembled outer walls of the central core of the cathedral from 1108, with cavities filled with lime mortar), fragments of plinthiform and ordinary bricks.

Both western aisles were built using bricks of the most common dimensions at that time $28-30 \times 15.5-17 \times 5.6-8 \mathrm{~cm}$.

The analysis of the state of the foundations of St Michael's Golden-Domed Cathedral concerning the strength of the plinthiform bricks (from the Old Russian period), bricks (from the seventeenth and eighteenth century) and masonry mortar showed insufficient adhesion of the mortar to both plinthiform and ordinary brick, due to its absence in some places of the foundation masonry. Masonry damage and cracks were observed. The plinthiform bricks were shattered in some places. The western aisle had partially preserved sections of foundations built using crushed bricks and rubble stone in the western and northern walls. In the northern aisle, foundations under the northern wall were observed to be made of rubble stone and crushed plinthiform bricks from the Old Russian parts of the cathedral. For masonry in both aisles, lime mortar with powdered overburnt brick was used.

An explosion destroyed both of the western aisles. The results of archaeological research proved that the flying buttress system in the southern, northern and western sides of the cathedral was a reinforcement measure used to strengthen the masonry on low-strength soil after the dismantling of the ancient Russian walls of the original church and the construction of new annexes to the cathedral. The depth of the footing within the framework of the plan of the cathedral varied: the depth of the footing of the flying buttresses was found to be 2.5-2.75 $\mathrm{m} ; 1.5-1.6 \mathrm{~m}$ for the apses; $2.16 \mathrm{~m}$ for the central apse; $2.32 \mathrm{~m}$ in the centre of the wall, and $0.6 \mathrm{~m}$ in the northern aisle. It was found that the strength of the footings and foundations of St Michael's Cathedral was further reduced because, in the process of archaeological research in 1996-1997, the foundations were left exposed for a year, which resulted in the footings suffering subbase damage.

The foundations of St Michael's belltower (1716-1719) showed signs of damage to the structure's integrity: fragments of the foundations were not connected in some places; the masonry was made of bricks of different quality, mostly with low load-bearing capacity; in some places, it was brittle. In the middle of the foundation, there was a wall with a two-layer structure, where the upper layer was made of brickwork, and the lower of small-sized rubble stone, similar to those in the outer part of the cathedral. The foundations of St Michael's belltower could not be used without additional strengthening and reinforcement.

The design documentation of the reconstruction of the buildings of St Michael's GoldenDomed Monastery was developed by TAM Yu. Losytskyi (Yurii Losytskyi Creative Architectural Studio). One of the most complicated tasks proved to be the construction the foundations of St Michael's Golden-Domed Cathedral and the bell tower. It was solved by accounting for the results of historical, archaeological and engineering-geological surveys and studies of the state of materials of the existing foundations, as well as the requirements for their museumification, exposition and the possibility of further archaeological research. 


\section{Archaeological studies of the Holy Dormition Cathedral of the Kyiv-Pechersk Lavra Historico-Cultural Preserve}

The Holy Dormition (Assumption) Cathedral was the first building of the Kyiv-Pechersk Monastery to be built of stone. Founded in 1073, it was erected in 1075-1077, and on 14 August 1089 the cathedral was consecrated. The cathedral consisted of one storey built on a cruciform plan with a single cupola supported by six columns. It had three naves, which on the outside terminated in many-faced apses. The cathedral was a three-nave, six-pillared, singlecupola, cruciform (cross-shaped) church, brightly decorated inside. During the temporary occupation of Kyiv in 1941-1943, on 3 November 1941, the Dormition Cathedral was blown up. The activity of the Kyiv-Pechersk Preservation was renewed after the end of the Second World War. The works were organised to dismantle the rubble from the destroyed buildings on the grounds of the Upper Lavra. In 1945, an architectural workshop headed by Methodius Dyomin performed measurements to budget the restoration. In the first post-war years, restorers developed methods for rebuilding the destroyed cathedral.

The cathedral ruins were dismantled. In September 1946, under the leadership of Professor L. Leontovych, calculations of the volume of the rubble of the Dormition Cathedral that had remained after the dismantling of the ruins of the cathedral in 1945 were performed. In 1945, the staff of the Kyiv-Pechersk Preserve undertook an architectural and archaeological investigation of the cathedral. At the same time, a design proposal for the restoration of the Chapel of St John the Theologian and the altar part of the southern nave was submitted; in the autumn of 1946, the corresponding project was developed and approved. From 1946 to 1948, the Chapel of St John the Theologian, the southern part of the eleventh-century cathedral and the annex, in which the sacristy was located, were cleared from the rubble. In the years 1946-1949, corresponding reports and academic publications about the history of the Dormition Cathedral were made. In 1947-1948, most of the rubble was removed. The next stage of architectural and archaeological research under M. Kholostenko's leadership began in 1951 and June-October $1952 .^{8}$

In 1954, the ruins were partially dismantled in the direction from west to east. In the post-war years, scientific research of the building materials and structures of the Dormition Cathedral continued, based on field surveys, photographic recordings and laboratory studies of samples. This allowed the classification of the samples of plinthiform brick, plaster and mortars. In 1955 , the results of studies performed in previous years were published.

Starting in July 1962 and lasting for the major part of the year, the last period of dismantling the rubble of the Dormition Cathedral took place and made it possible to determine the state of preservation of the structures of the cathedral, to identify the emergency areas, collect samples of building materials, and continue the measurement and research work. Two versions of the design documentation of the conservation of the ruins of the Dormition Cathedral were developed in 1963. Basing on them, "the proposals for the conservation of the object were drawn up and were implemented in 1965-1967".?

As O. Sitkarova noted, in 1962-1964, "there was a transition from purely conservation work to solving the complex task of restoring the cathedral". ${ }^{10}$ In ancient times, no survey of the

\footnotetext{
${ }^{8}$ ORLENKO, Mykola. Assumption Cathedral of the Kyiv-Pechersk Lavra: methodological principles and chronology of reproduction. Kyiv, 2015, p. 832.

${ }^{9}$ PETICHINSKIY, Volodymyr, GOVDENKO, Georgij, and GOVDENKO, Marionila. Report on the dismantling..., pp. 10-16.

${ }^{10}$ SITKARYOVA, Assumption Cathedral..., p. 232.
} 
cathedral was carried out, and the first mention of an engineering survey dated back to 1787. Complex soil conditions at the construction site led to subsidence, and then to the appearance of cracks in the structural elements of the church, which raised the question of the need for repair. "The Dormition Cathedral..." was studied by provincial architect Prezant and architect Buzzi. According to these experts, the deformations in the church led mainly to an uneven precipitation of the additions to the cathedral at different times, due to the dampening of the foundations, which did not have a reliable sealed area. The architects suggested "to close up $[\ldots]$ the cracks with iron, brick or stone wedges [...] with lime and alabaster", as well as "to dig a ditch around the church with a depth of three arshins, and a width of three [...] see if there are any holes there, fill them and to pack a sub-grade, and fill all this dug-in place with clay with a slope satisfied from the wall and then pave the still strong stone pavement". ${ }^{11}$ It is not known whether the recommendations for the construction of a "clay castle" and a stone-blind area along the entire perimeter of the structure were fully implemented. It is only documented that the paving of flaky natural stone, which had fallen into disrepair by 1783, was redone in 1789 .

Unlike St Michael's Golden-Domed Cathedral, here attention had already been focused on the ruins of the Dormition Cathedral since 1945. The clearing of the debris that had been left of the destroyed parts of the church began immediately after the end of the Second World War and lasted well into 1963. The dismantling of the rubble was accompanied by measurements, detailed photographic surveys, archaeological excavations and a field survey of the monument. In addition, the need to restore the Dormition Cathedral was voiced for the first time already in 1945.

The existing utility facilities, namely the sewerage and stormwater drainage systems, the heating grid and other auxiliary grids, were in a dilapidated state, which negatively affected the general engineering and technical state of the area, and led to a deterioration in the groundwater regime and to deformations of the structures of buildings located near the cathedral.

Since the main reason for the increased soil water content was water leakage from aquifers, it was necessary to choose the safest means of laying utility grids.

Loess soils with a depth of 8-12 $\mathrm{m}$ under the foundations of the Dormition Cathedral created a threat of uneven deformations when wet, which is why it was necessary to create an almost nondeformable foundation for the cathedral. ${ }^{12}$

Previous studies of the ruins of the Dormition Cathedral established the following:

- there were no foundations at the epicentre of the explosion - within a radius of up to 8-10 $\mathrm{m}$ from the epicentre of the explosion, the foundations were partially preserved;

- the foundations of the central part were all but completely destroyed;

- the foundations from the seventeenth and eighteenth centuries were preserved and only needed reinforcement.

Within the structure, there was a significant discrepancy both in footing level and the materials from which the foundations were made due to the different construction times of various parts of the cathedral. For the footings, blocks of sandstone, plinthiform bricks, white limestone mortar with an admixture of crushed ceramics, grey lime-sand mortar, pale pink lime mortar with powdered overburnt brick and lime-sand mortar with the addition of white brick of the eighteenth century, were used.

\footnotetext{
${ }^{11}$ Ibidem.

${ }^{12}$ ORLENKO, Assumption Cathedral of the Kyiv-Pechersk Lavra..., p. 832.
} 
The foundations of the northern apse expanded inward, and their lower part was composed of large dry stones. The dimensions of the stones from which the foundations were made in the north-western part of the cathedral increased along with footing level. As mentioned earlier, according to the studies carried out, the following, higher-precision periodisation of the construction of the cathedral was adopted: first period (1073-1109), second period (between 1109 and the second half of the twelfth century), third period (between the thirteenth and the fifteenth centuries), fourth period (between the sixteenth century and the 1630s), fifth period (1638-1677), sixth period (between the 1690s and 1718), seventh period (1718-1780) ${ }^{13}$ (Fig. 4).

Within each period, several stages were identified and the nature and characteristics of each of them were formulated. In the first period of construction, three stages were distinguished: 1073-1087, 1088-1089 and between the 1090s and 1109. In the first stage, the masonry of the original massing of the cathedral was made of plinthiform brick, using the opus mixtum tech-

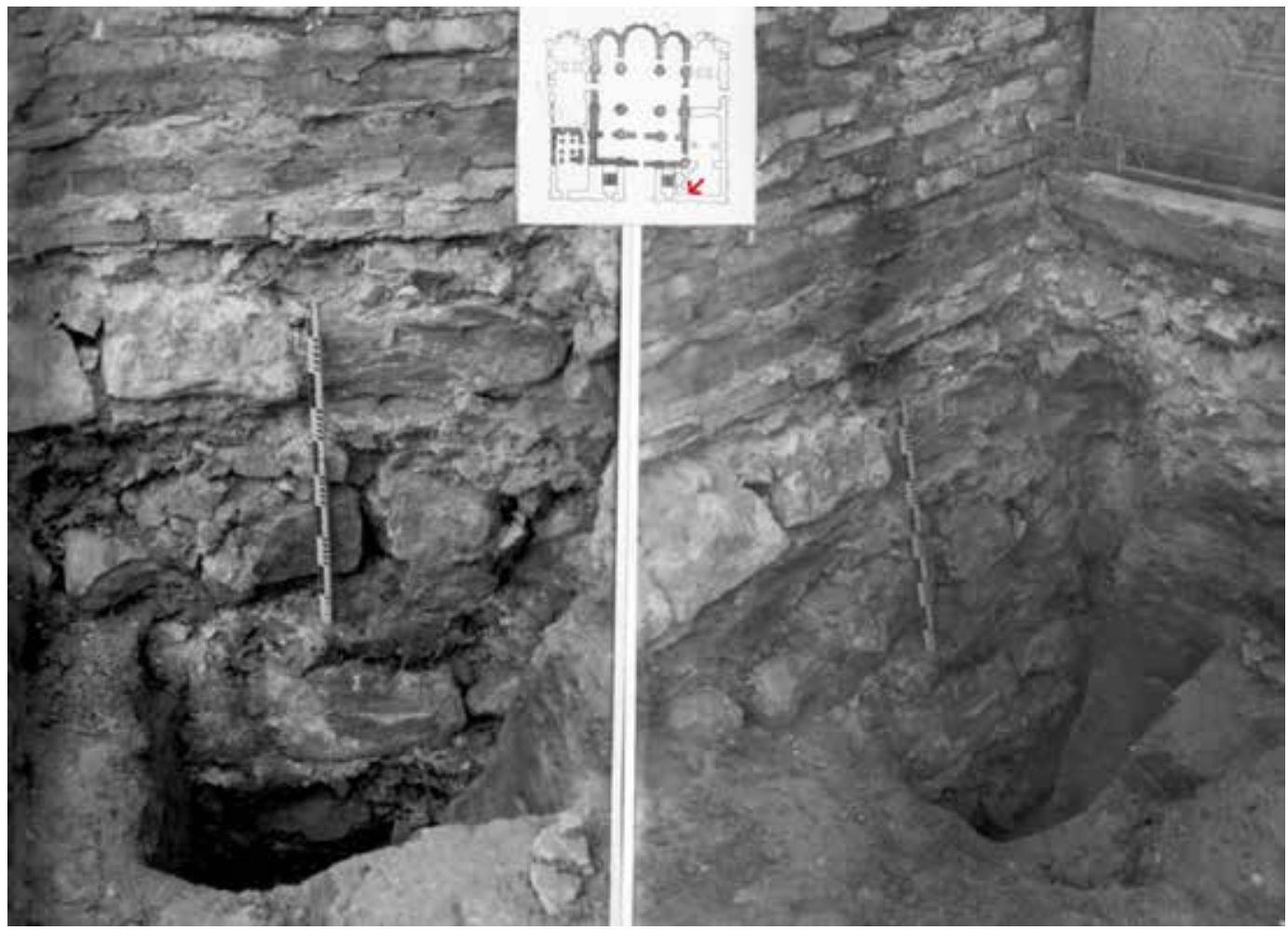

Fig. 4: The Dormition Cathedral. Excavation site no. 20 b. Pit in the north-western corner of the southern vestibule to determine the footing level. Photo: [in:] Collection of the Ukrrestavratsiia Corporation.

nique and with a recessed course, using stones of significant size (Fig. 5). At certain levels, the masonry of the Dormition Cathedral was dissected by peculiar reinforcing strips in the form of flat slabs of dark red Ovruch slate. For the surface structure of the cathedral and the backfilling of the foundations, a light pink lime mortar with powdered, high-density, high-strength overburnt brick was used.

In the original masonry of the Old Russian section of the Dormition Cathedral, lime mortars with powdered overburnt brick were used. The technology behind these mortars devel-

${ }^{13}$ SITKARYOVA, Assumption Cathedral..., p. 232. 
M. Orlenko et al.: Study of foundations in Ukraine from the eleventh to eighteenth centuries...

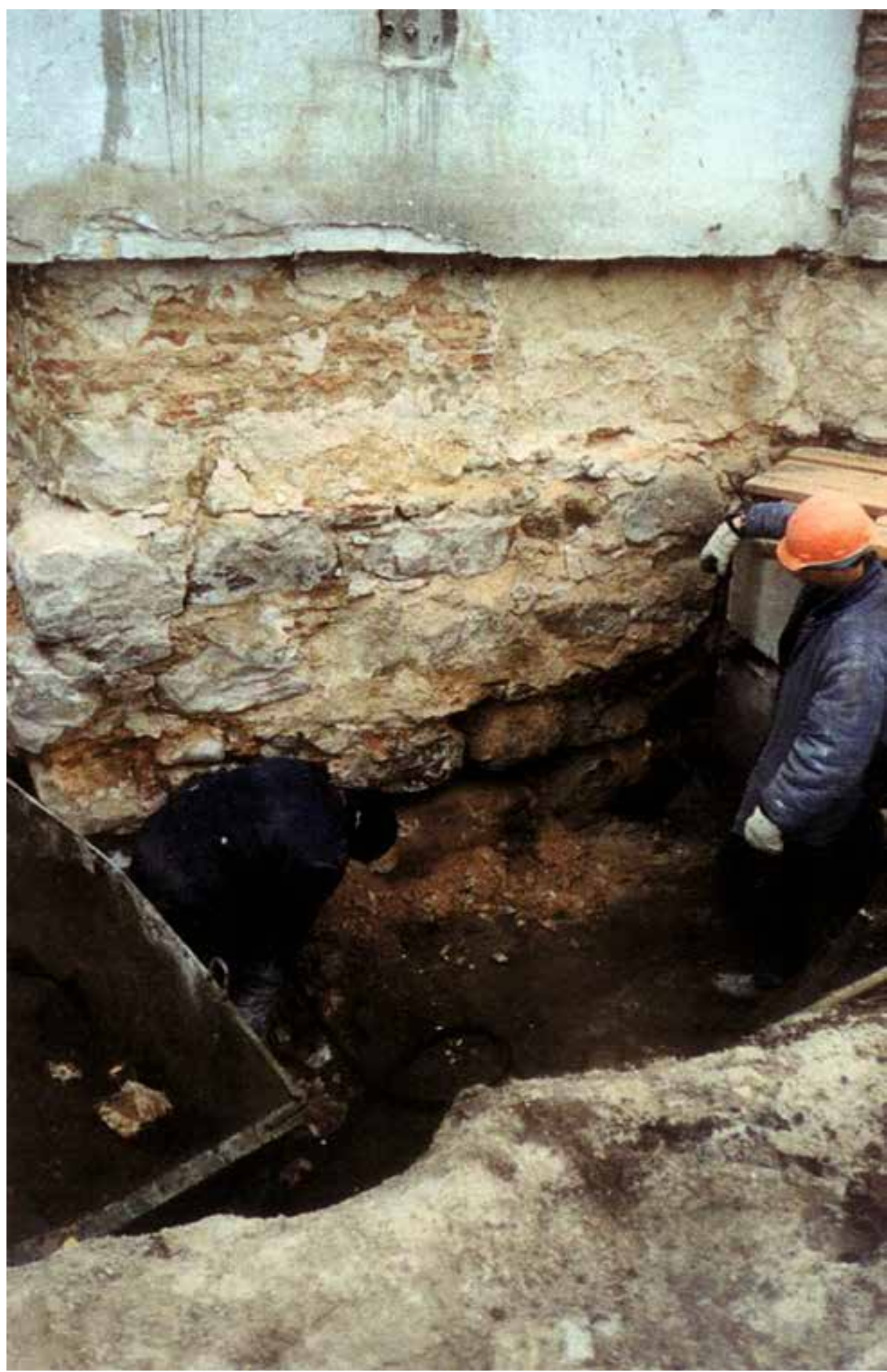

Fig. 5: Fragment of ancient foundations of the Dormition Cathedral. Photo: [in:] Collection of the Ukrrestavratsiia Corporation 
oped under the influence of Greek and Byzantine technologies, when powdered ceramics, the so-called opus signinum, was added to lime binder in the form of aggregate. Construction technology using the lime mortar with powdered overburnt brick existed for almost three hundred years, from the tenth to the thirteenth centuries, in Kyivan Rus.

During a 1998 investigation, the results of the 1972-1986 study were analysed, systematised and supplemented. In particular, it was noted that the construction in 1986-1987 around the spot of the cathedral up to the height of a decorative structure covered with sand and an asphalt podium, for basing heavy mechanisms during the restoration of the cathedral, led to a deterioration in the conditions and state of preservation of the remains of the Dormition Cathedral as a pool of water formed around them, as stormwater got inside the ruins and accumulated under layers of decorative masonry, asphalt and concrete floors. As there was no drainage system in place, the moisture content of the soil and masonry under the surface was $25 \%$, that is, the structures were saturated with moisture. ${ }^{14}$ Long-term freezing and thawing cycles turned the surface layer of the ancient structure to the freezing depth into a loose conglomerate. The site on which the Dormition Cathedral is located was conditionally divided into three zones: a zone of destruction within the epicentre of the explosion, a zone of significant damage with the remains of ancient walls, and a zone of partial damage with the Chapel of St John the Theologian, which survived the explosion.

The complexity of the tasks was that a significant part of the ruins turned out to be split into separate elements and deformed, and according to restoration requirements, all the remains of ancient structures had to be preserved and the possibility of their further study had to be provided. In addition, the Chapel of St John the Theologian was in an alarming, pre-failure state. The studies of the state of the foundations, carried out earlier by the Scientific Research Institute of Building Structures, using the electric wave method, found defects of the masonry in the body of some foundations. Foundations under the northern wall from the eleventh century showed signs of significant damage ${ }^{15}$ Cracks, displacements and missing fragments were recorded in the strip foundations between the north wall and the northwest dome column. Cracks and missing fragments in the masonry were also recorded in the foundations of the southern wall. The foundations in the north-western corner of the sacristy were in relatively good condition.

The difficulty was also in the fact that the depth of the foundations in different parts of the cathedral differed. For example, the bottom of the foundation of the southern wall, which consisted of large blocks of sandstone bound with lime mortar with powdered overburnt brick of a pale pink colour, was located at a depth of $2.5 \mathrm{~m}$. The bottom of the foundations of the north-western part of the cathedral, which consisted of horizontal courses of large sandstone blocks bound by lime-sand mortar with the inclusion of white bricks, was located at a depth of $2.75 \mathrm{~m}$ from the level of the slabs of conservation floors. The bottom of the foundation of the northern apse, which consisted of stone and plinthiform bricks on white lime mortar with an admixture of powdered ceramics, was located at a depth of $3.6 \mathrm{~m}$ from the asphalt level. The footing level of the buttress at the place where the southern apse adjoins the central one was at a depth of $3.30 \mathrm{~m}$ from the asphalt level, and the foundation itself consisted of large stones with plinthiform bricks on the grey lime-sand mortar.

\footnotetext{
${ }^{14}$ ORLENKO, Mykola. Assumption Cathedral of the Kyiv-Pechersk Lavra..., p. 832.

${ }^{15}$ Ibidem.
} 
M. Orlenko et al.: Study of foundations in Ukraine from the eleventh to eighteenth centuries...

It was noted that the plinthiform brick and masonry mortars of the eleventh century are among the most durable in the monuments of Kyivan Rus of the pre-Mongol period; therefore, the re-preservation of the remains of the cathedral's masonry from the upper layer should be done urgently to use the summer period to dry the entire section of the cathedral. It was proposed to extract the masonry block of the pylon from the eleventh century from the cathedral site, so as to conserve and preserve it as a kind of memory of the destroyed unique structure. ${ }^{16}$

\section{Conclusions}

The experience of the Ukrrestavratsiia Corporation in reconstructing destroyed monuments of architecture testifies to the expediency and fundamental possibility of preserving valuable remains (foundations, fragments of walls, ceilings and vaults, decorative elements etc.), as well as of reproducing outstanding architectural monuments using modern restoration and reconstruction technologies. ${ }^{17}$

Stone walls were: of the opus mixtum type and from rubble masonry made of sandstone, granite, quartzite, plinthiform brick bound with the lime mortar with powdered overburnt brick (between the tenth and eleventh centuries); with masonry from plinthiform brick in courses bound with lime mortar (between the tenth and eleventh centuries); with rubble masonry of sandstone bound with lime mortar (between the eleventh and seventeenth centuries), with rubble ashlar masonry (limestone, sandstone, tuff) from two layers of the front shell with backfilling bound with lime, lime with charcoal and lime mortar with powdered overburnt brick (the eleventh century); with regular-coursed rubble stone masonry of red bricks bound with lime and lime mortar with powdered overburnt brick (between the sixteenth and eighteenth centuries); and with regular-coursed rubble stone masonry of yellow brick bound with lime and lime mortar with powdered overburnt brick (between the nineteenth and twentieth centuries).

Over the past decades, restoration work has been carried out on St Michael's Golden-Domed Monastery, the Holy Dormition Cathedral of the Kyiv-Pechersk Lavra (Fig. 6), the Pyrohoshcha Dormition of the Mother of God Church in Podil, the monument to Princess Olga and Saints Cyril and Methodius, and St Vladimir's Cathedral in Chersonesos, which are of great importance as symbols of Ukrainian statehood as examples of the architecture of their respective periods. Of many unique monuments, only their foundations remained (the Church of the Tithes, the Pyrohoshcha Dormition of the Mother of God Church in Podil, St Michael's Golden-Domed Cathedral with a bell tower); in some, in addition to the foundations, walls and individual fragments remained (St Vladimir's Cathedral in Chersonesos, the Dormition Cathedral of the Kyiv-Pechersk Lavra). In this case, the main restoration task was the maximum preservation of artifacts - foundations, walls, aisles and chapels. In the process of reproduction, the task was to provide access to the historical foundations for further research and observation by visitors (St Michael's Golden-Domed Cathedral) wherever possible.

The comparative analysis of the archaeological remains of the foundations of two unique structures from the Old Russian period - St Michael's Golden-Domed Cathedral and the Dormition Cathedral of the Kyiv-Pechersk Lavra - made it possible to determine the types of foundation masonry and building materials used, and to emphasize that at that time there

\footnotetext{
${ }^{16}$ ORLENKO, Assumption Cathedral of the Kyiv-Pechersk Lavra..., p. 832.

${ }^{17}$ ORLENKO, St. Michael's Golden-Domed Monastery..., p. 160; ORLENKO, St. Volodymyr's Cathedral in Chersonesos..., p. 320; ORLENKO, Assumption Cathedral of the Kyiv-Pechersk Lavra..., p. 832.
} 


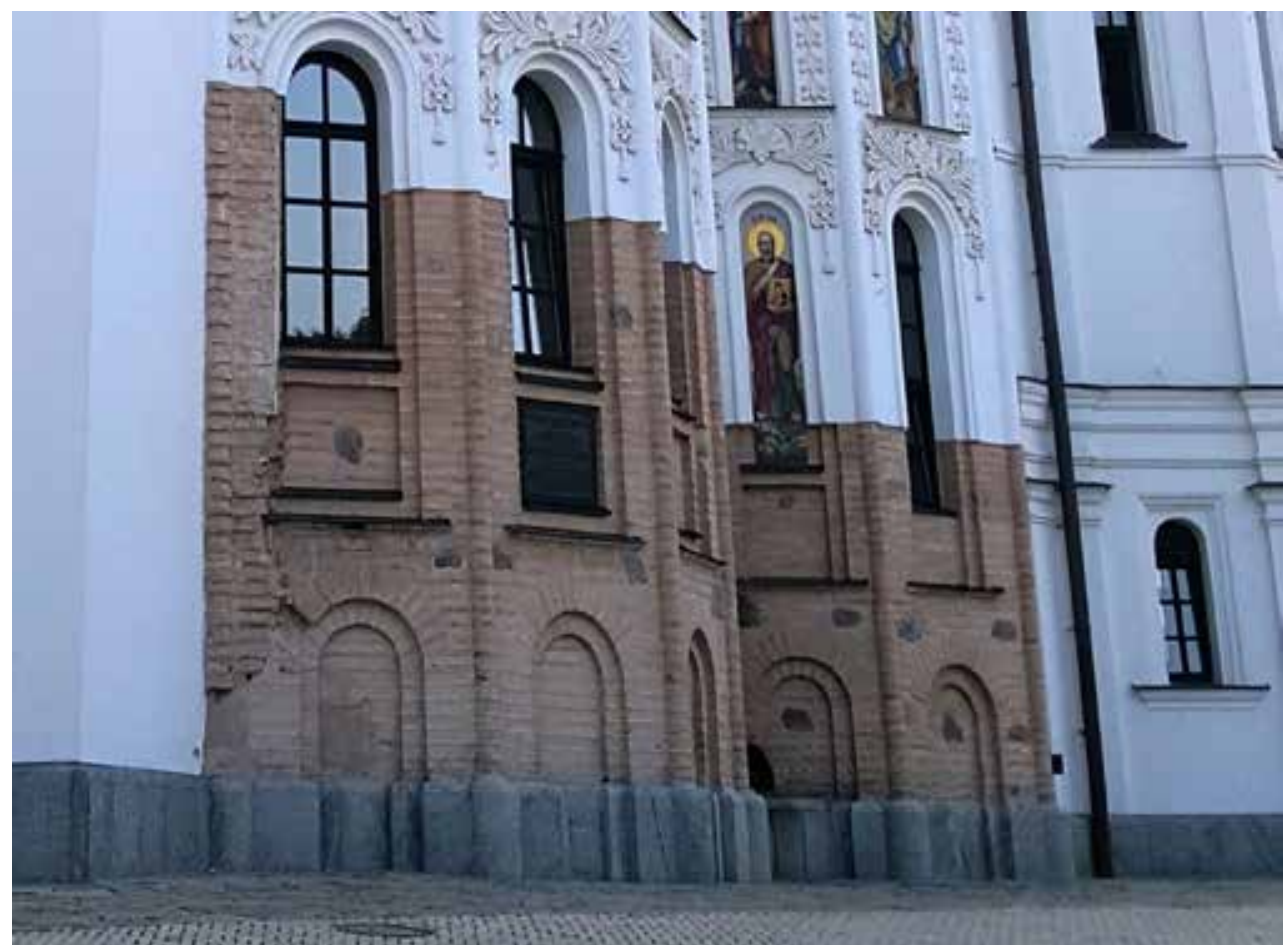

Fig. 6: Reconstruction of old masonry techniques on the apses of the Dormition Cathedral. Photo by D. Kuśnierz-Krupa, 2019

was a large number of combinations of building materials and solutions for the laying of foundations, which is noticeable even using the example of the two principal temples:

In St Michael's Golden-Domed Cathedral (Fig. 7):

1) in the Old Russian period - foundations were made from large rubble stone bound with lime mortar with powdered overburnt brick, in the foundation ditches, additionally reinforced with wooden beds and iron pins; in some foundations of the twelfth century - a layer-by-layer structure with a lower layer of the cyclopean masonry made of irregularly shaped stones without mortar, with soil-filled cavities, a middle layer of rubble cement masonry from crushed plinthiform brick and boulders bound with lime mortar, and an upper layer of plinths using lime mortar was used; in some foundations from the twelfth and thirteenth centuries foundations were constructed using plinthiform brick bound with lime and lime-clay mortar, without binding the stones in isolated and strip footings; from broken bricks and rubble stone bound with the lime mortar with powdered overburnt brick;

2) in the Baroque period of the seventeenth and the early eighteenth centuries - foundations were made of red bricks and internal brickwork of rubble stone (from the partially disassembled external walls of the central core of the cathedral in 1108, with cavities filled with lime mortar), fragments of plinthiform bricks and bricks, as well as brickwork masonry measuring 28-30 x $15.5-17 \times 5.6-8 \mathrm{~cm}$.

In the Dormition Cathedral (Figs 8, 9):

1) in the Old Russian period - masonry from plinthiform brick, using the opus mixtum technique and with a recessed course with the use of a significant number of boulders, bound 
with lime mortar with powdered overburnt brick with the addition of a filler to the lime binder - powdered ceramics (opus signinum) was used; in some foundations dated to the eleventh century - the masonry consisted of large blocks of sandstone bound with lime mortar with powdered overburnt brick, from rubble masonry bound with the lime mortar with powdered overburnt brick, from stone and plinthiform brick bound with lime mortar with powdered ceramics; some foundations from the eleventh and twelfth centuries consisted of stone and fragments of plinthiform bricks bound with lime mortar with powdered overburnt brick, from plinthiform brick and stone of various sizes bound with lime-sand mortar, from cut and uncut stone blocks; in some foundations of the thirteenth century - uncut stone bound with limesand mortar was utilised.

2) in the Baroque period of the seventeenth and early eighteenth century - foundations consisted of large sandstone blocks bound with lime-sand mortar with the addition of white brick from the eighteenth century.

One crucial problem is that the churches of the Old Russian period were repeatedly destroyed and rebuilt over the centuries; therefore, they had layers from different times from the seventeenth, eighteenth, nineteenth and early twentieth centuries. The same applies to structures from the seventeenth and eighteenth centuries, which were reconstructed on a massive scale in the synodal period of the nineteenth century. Therefore, when reproducing damaged or destroyed buildings, the concept of reconstructing the external and internal appearance was adopted, taking into account all periods of a monument's existence, as it had appeared in the years of its maximum prosperity.

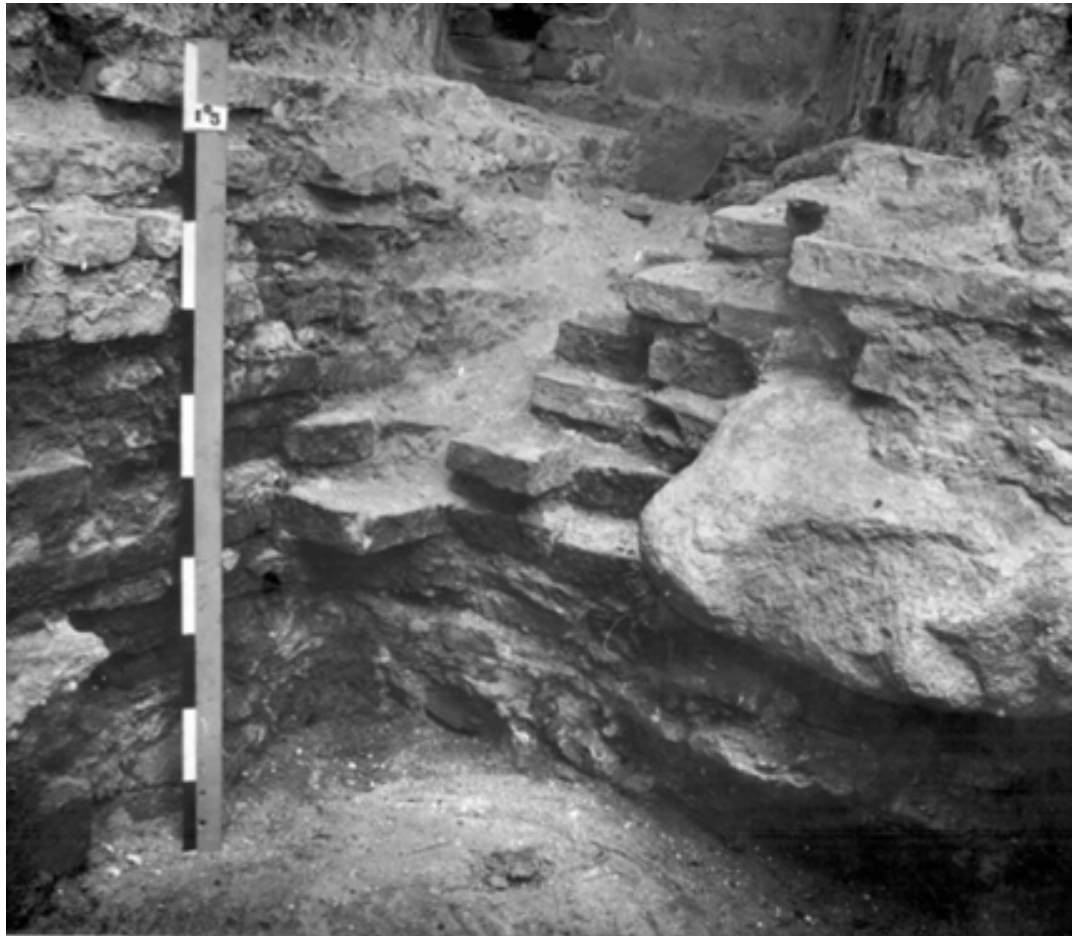

Fig. 7: Ruins of old foundation masonry of St Michael's Golden-Domed Cathedral. Photo: [in:] Collection of the Ukrrestavratsiia Corporation 

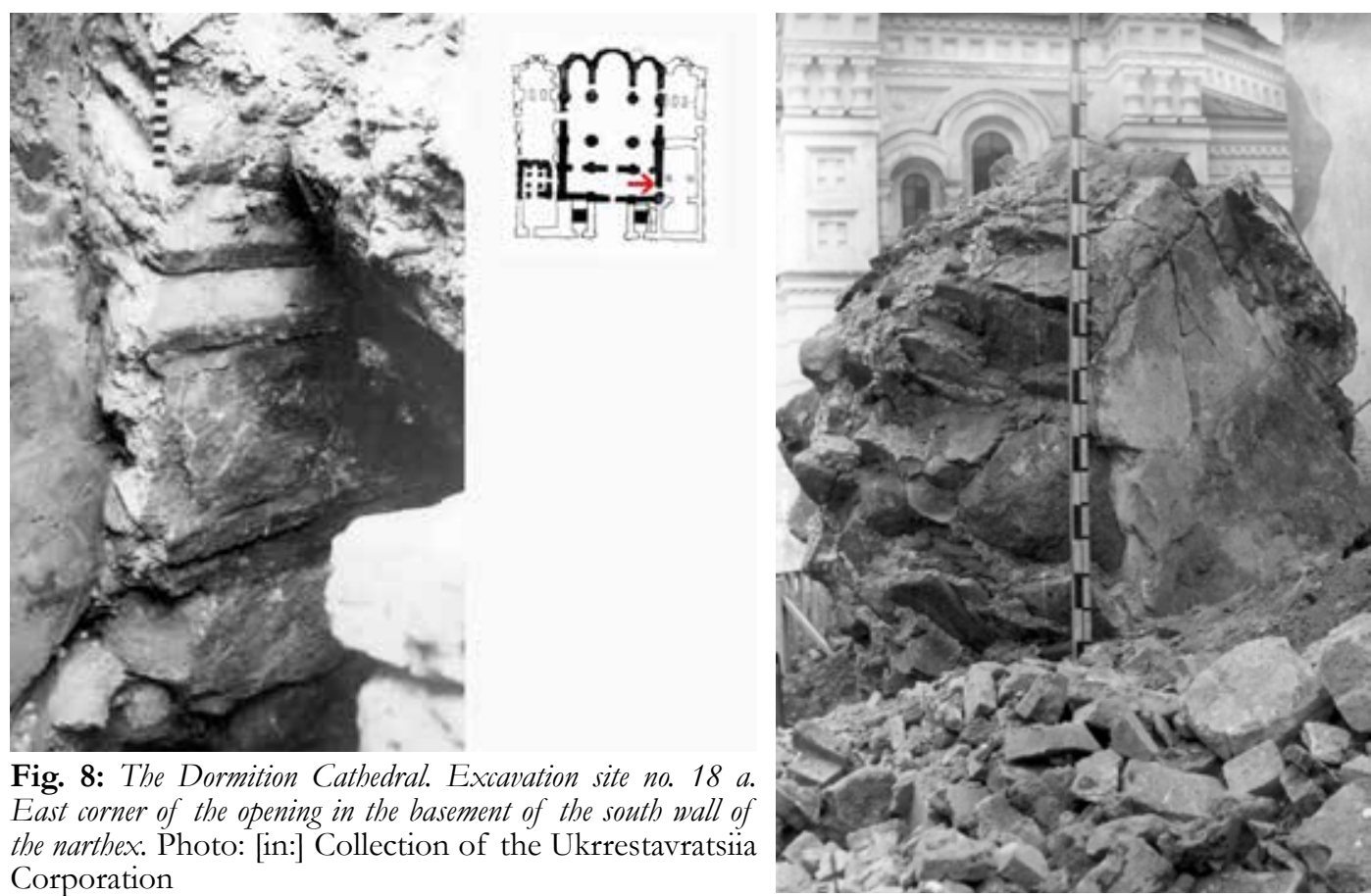

Fig. 8: The Dormition Cathedral. Excavation site no. 18 a East corner of the opening in the basement of the south wall of the narthex. Photo: [in:] Collection of the Ukrrestavratsiia Corporation

Fig. 9: The Dormition Cathedral. Ruins of old masonry. Photo: [in:] Collection of the Ukrrestavratsiia Corporation

In this context, it must be noted that historical relics from the times of Halych Ruthenia have also been preserved in Poland. One excellent archaeological specimen of a building from the times of Prince Daniel Romanovich, also known as Daniel of Galicia, is located in Chełm. It is known that at the beginning of the thirteenth century, the duke of Halych-Volodymyr Daniel Romanovych founded a fortified town in what is present-day Chelm. ${ }^{18}$ This location was dictated by the fact that these areas, located in the western part of the principality, were the least endangered by the Tatars. The stronghold was erected on a mountain surrounded by forests (now called Cathedral Hill). Here, also in the thirteenth century, a church was built, at whose site the present-day church of the Holy Nativity of the Blessed Virgin Mary was built in the eighteenth century. ${ }^{19}$

Archaeological research has been carried out over several years to determine the exact location and shape of the thirteenth-century church and the burial place of Daniel Romanovych. ${ }^{20}$ It is known for certain that the church founded by Romanovych was smaller than the current one and that it was one of many buildings included in the castle complex from the times of

\footnotetext{
${ }^{18}$ BUKO, Andrzej, (ed). Średniowieczny zespół rezydencjonalny na Górze Katedralnej w Chełmie, Warszawa, 2019. ${ }^{19}$ KRASNY, Piotr. Katedra unicka w Chełmie: O problemach badań nad architekturą sakralną kościoła greckokatolickiego w XVIII wieku. In: J.K. Ostrowski eds. Sztuka Kresów Wschodnich: materiały sesji naukowej 3, 1998, Kraków, p. 205-219; BUKO, Andzrej. Źródła pisane i archeologia: przykład Góry Katedralnej w Chełmie, Kwartalnik Historyczny CXXIII (2), 2016, p. 221-246.

${ }^{20}$ DĄBROWSKI, Dariusz. Rodowód Romanowiczów, książąt halicko - wołyńskich, Poznań - Wrocław, 2002.
} 
M. Orlenko et al.: Study of foundations in Ukraine from the eleventh to eighteenth centuries...

Halych Ruthenia. Research on its alleged shape was carried out in 2013-2014 ${ }^{21}$ and is still ongoing as of the writing of this paper.

The archaeological research at Cathedral Hill in Chełm into the buildings related to the heritage of Halych Ruthenia will be continued as the hill still hides many secrets.

\section{References}

BUKO, Andrzej. (2016). Źródła pisane i archeologia: przykład Góry Katedralnej w Chełmie. In: Kwartalnik Historyczny CXXIII (2), pp. 221-246. ISSN: 0023-5903

BUKO, Andrzej, and GOEUB, Stanisław. (2016). Od Cerkwi Katedralnej króla Daniela Romanowicza do basyliki pw. Narodzenia NMP w Chetmie. Wyniki badań interdyscyplinarnych sezonu 2013-2014. Muzeum Ziemi Chełmskiej im. Wiktora Ambroziewicza w Chełmie, Chełm, ISBN 978-8389942-39-5

BUKO, Andrzej (eds). (2019). Średniowieczny zespót reazydencjonalny na Górze Katedralnej w Chetmie, Warszawa. ISBN: 978-83-953153-9-8

DĄBROWSKI, Dariusz. (2002). Rodowód Romanowiczów, ksiażat halicko - wotyńskich. Poznań Wrocław, ISBN: 83-913563-8-8

IVASHKO, Yulia, DMYTRENKO, Andrii, PAPRZYCA, Krystyna, KRUPA, Michał, and KOZLOWSKI, Tomasz. (2020). Problems of historical cities heritage preservation: Chernihiv Art Nouveau buildings. In: International Journal of Conservation Science 11 (4), pp. 953-964, ISSN: 2067-8223

JASIEŃKO, Jerzy, BEDNARZ, Łukasz, MISZTAL, Witold, and RASZCZUK, Krzysztof. (2010). Konserwacja konstrukcyjna i wzmacnianie murów historycznych. In: B. Szmygin (ed.), Trwata ruina II. Problemy utraymania $i$ adaptacji. Ochrona, konserwacja $i$ adaptacja zabytkowych murów. ICOMOS, pp. 57-68, ISBN: 978-83-62596-17-1

KRASNY, Piotr. (1998). Katedra unicka w Chełmie: O problemach badań nad architektura sakralną kościoła greckokatolickiego w XVIII wieku. In: J.K. Ostrowski (ed.), Sztuka Kresów Wschodnich: materiaty sesji naukowej 3. Kraków, pp. 205-219, DOI: https:/ /doi.org/10.11588/ diglit. 22257

KUŚNIERZ-KRUPA, Dominika. (2018). Protection issues in selected European historic towns and their contemporary development. In: E3S Web of Conferences 45, pp. 1-8, eISSN: 2267-1242

KUŚNIERZ-KRUPA, Dominika. (2019). Historical Buildings and the Issue of their Accessibility for the Disabled. In: IOP Conference Series: Materials Science and Engineering, 603 (5), pp. 1-6, ISSN: 1757-8981

LUVIDI, Loredana, MECCHI, Anna Maria, FERRETTI, Marco, and SIDOTI, Giancarlo. (2016). Treatments with self-cleaning products for the maintenance and conservation of stone surfaces. In: International Journal of Conservation Science 7 (S. Iss. 1), pp. 311-322, ISSN: 2067-8223

\footnotetext{
${ }^{21}$ BUKO, Andrzej and GOŁUB, Stanisław. Od Cerkwi Katedralnej króla Daniela Romanowicza do bazyliki pw. Narodzenia NMP w Chełmie. Wyniki badań interdyscyplinarnych sezonu 2013-2014, Muzeum Ziemi Chełmskiej im. Wiktora Ambroziewicza w Chełmie, Chełm, 2016.
} 
ORLENKO, Mykola. (2019). The system approach as a means of restoration activity effectiveness, In. Wiadomości Konserwatorskie - Journal of Heritage Conservation, 57, pp. 96 -105, ISSN 0860-2395

ORLENKO, Mykola. (2002). St. Michael's Golden-Domed Monastery: methodological principles and chronology of reproduction. Kyiv, ISBN:966-532-018-1

ORLENKO, Mykola. (2015). St. Volodymyr's Cathedral in Chersonesos: methodological principles and chronology of reproduction. Kyiv, ISBN: 978-966-136-562-8

ORLENKO, Mykola. (2015). Assumption Cathedral of the Kyiv-Pechersk Lavra: methodological principles and chronology of reproduction. Kyiv, ISBN: 978-966-136-263-4

PETICHINSKIY, Volodymyr, GOVDENKO, Georgij, and GOVDENKO, Marionila. (1964). Report on the dismantling of the ruins of the Assumption Cathedral - an architectural monument of the XI-XVIII centuries in the Kyiv-Pecherkyi State Historical and Cultural Reserve in 1962-1963. Kiev, pp. 10-16, conservation document.

PUJIA, Laura. (2016). Cultural heritage and territory: Architectural tools for a sustainable conservation of cultural landscape. In: International Journal of Conservation Science 7 (S. Iss. 1), pp. 213-218, ISSN: 2067-8223

SITKARYOVA, Olga. (2000). Assumption Cathedral of the Kyiv-Pechersk Lavra. Kyiv, ISBN:966507-094-0

SPIRIDON, Petronela, and SANDU, Ion. (2016). Muselife of the life of public. In: International Journal of Conservation Science 7 (1), pp. 87-92, ISSN: 2067-8223

TREHUBOV, Kostiantyn, DMYTRENKO, Andrii, KUZMENKO, Tetiana, and VILDMAN, Igor. (2020). Exploration and restoration of parts of Poltava's town fortifications during the Northern War and elements of field fortifications used in the Battle of Poltava in 1709. In: Wiadomości Konserwatorskie - Journal of Heritage Conservation 61, pp. 91-100, ISSN 0860-2395 